\title{
A lanterna de Faraday: relações conceituais em um cenário semiótico
}

\author{
João B. A. dos Reis (UNEC) \\ Maria Loiza Izidóro de Assis (UNEC) \\ Milheny Silva de Paiva (UNEC) \\ RESUMO-PÔSTER
}

\begin{abstract}
Evoca-se neste relato de pesquisa as relações conceituais referentes ao princípio da indução eletromagnética, aludindo-se a Michael Faraday (1791-1867) na Londres de 1831. Traçando trilhas entre a História da Ciência e Ensino e abordagens semióticas, na disciplina de Física Geral Experimental III, nos cursos de Engenharia do Centro Universitário de Caratinga. Conceitualmente as variações do fluxo magnético em relação a um circuito originam correntes elétricas, ímãs e solenoides movendo-se relativamente entre si. Associando-as à linguagem sígnica do cinema, buscou-se a ressignificação conceitual das correntes induzidas, vislumbrando-as em um aparato epistêmico: a lanterna de indução ou lanterna de Faraday. Metodologicamente, orientou-se na aplicabilidade utilitarista explicitada na trama inicial do Inferno da saga do escritor Dan Brown, sendo proposto que os alunos assistissem ao filme e/ou lessem o livro e evidenciassem paralelos entre ciência e artes cênicas. Obteve-se, inicialmente, nesse projeto de pesquisa, atenção e interesse entregues ao tema indução através de diversos caminhos e abordagens retiradas do filme e da leitura dos textos em História da Ciência e Ensino.
\end{abstract}

